\title{
KOMUNIKASI MEDIA SOSIAL DAN NILAI-NILAI BUDAYA PANCASILA SOCIAL MEDIA COMMUNICATIONS AND CULTURAL VALUES of PANCASILA
}

\author{
Luh Suryatni \\ luhsuryatni@gmail.com
}

\begin{abstract}
The third wave in human civilization according to Alvin Toffler is information technology which accelerates the communication process and interaction to convey information in social media. Medium of communication with the Internet network resulted in a socio-cultural changes which can be positive or negative. Positive changes can facilitate intercultural communication, exchange of knowledge, and simplify business transactions. Meanwhile, the negative changes will have a cultural shock as the impact because of the information which was obtained from social media is taken for granted, believed to be true and applied in everyday life even though it is not in accordance with the surrounding culture. This can lead to changes in values, norms, and rules of communication. In connection with social media, it is regulated in Law No. 11 Year 2008 on Electronic Transaction Information (ITE) as a social control in conveying information based on Constitution of the Republic of Indonesia 1945 (UUD NRI 1945) article 28, which can reflect the cultural values of Pancasila.
\end{abstract}

Keywords: Communication, Social Media, Cultural Values of Pancasila

\begin{abstract}
ABSTRAK
Gelombang ketiga dalam peradaban umat manusia menurut Alvin Toffler adalah teknologi informasi yang mempercepat terjadinya proses komunikasi dan interaksi untuk menyampaikan informasi dalam media sosial. Medium komunikasi dengan jaringan internet mengakibatkan terjadinya perubahan sosial budaya yang dapat bersifat positive maupun negatif. Perubahan yang bersifat positif dapat mempermudah komunikasi antar budaya, pertukaran pengetahuan, dan mempermudah transaksi bisnis. Sementara itu, perubahan yang bersifat negatif akan berdampak pada geger budaya karena informasi yang diperoleh dari media sosial diterima begitu saja, diyakini kebenarannya dan diterapkan dalam kehidupan keseharian walaupun sebenarnya tidak sesuai dengan budaya sekitar. Hal ini dapat menyebabkan perubahan nilai, norma, maupun aturan dalam berkomunikasi. Sehubungan dengan media sosial, sudah diatur dalam UU No 11 Tahun 2008 tentang Informasi Transaksi Elektronik (ITE) sebagai control sosial dalam menyampaikan informasi berdasarkan UUD NRI 1945 pasal 28, yang dapat mencerminkan nilai-nilai budaya Pancasila.
\end{abstract}

Kata kunci : Komunikasi, Media Sosial, Nilai-Nilai Budaya Pancasila. 


\section{PENDAHULUAN}

Kemajuan teknologi dan informasi tidak dapat di pungkiri telah membawa perubahan - perubahan social baik maupun tidak baik yang dapat mempengaruhi kehidupan umat manusia. Oleh Alvin Toffler dikatakan sebagai "Gelombang Ketiga" peradaban umat manusia yakni teknologi dan informasi. Hal ini akan membuat bumi menjadi sempit, seolah - olah sebuah ruang atau desa paguyuban (geminschaft) yang transparan, yang disebut sebagai "Desa Buwana (Global Village). Pada gelombang pertama umat manusia memasuki zaman pertanian sedangkan gelombang kedua umat manusia adalah zaman industri, yang selanjutnya gelombang ketiga peradaban umat manusia adalah zaman teknologi dan informatika. Pada gelombang ketiga ini di lambangkan oleh silicon dan microchip sebagai komponen teknologi kecerdasan buatan (arti fisial intelligence) seperti komputer, internet, ponsel, dan lain - lain. Zaman informatika ditandai dengan mudahnya menjalin komunikasi timbal balik antara berbagai kelompok umat manusia di seluruh penjuru dunia.

Paguyuban (geminschaft) menurut Charles Horton Cooley merupakan bentuk kehidupan bersama di mana anggota - anggotanya di ikat oleh hubungan batin yang murni dan bersifat alamiah serta bersifat kekal berdasarkan rasa cinta dan rasa kesatuan batin yang memang telah dikodratkan. (Soekanto, $2003: 132$ )

Manusia adalah makhluk sosiobudaya yang memperoleh perilakunya lewat belajar. Apa yang kita pelajari pada umumnya dipengaruhi oleh kekuatan-kekuatan sosial dan budaya. Dari semua aspek belajar manusia, komunikasi merupakan aspek yang terpenting dan paling mendasar. Kita belajar banyak hal lewat responsrespons komunikasi trhadap rangsangan dari lingkungan. Kita harus menyandi dan menyandi balik pesan-pesan dengan cara itu sehingga pesan-pesan tersebut akan dikenali, diterima, dan direspons oleh individu-individu yang berinteraksi dengan kita. Bila dilakukan, kegiatankegiatan komunikasi berfungsi sebagai alat untuk menafsirkan lingkungan fisik dan sosial kita. komunikasi merupakan alat utama kita untuk memanfaatkan berbagai sumber daya lingkungan dalam pelayanan kemanusiaan. Lewat komunikasi kita menyesuaikan diri dan berhubungan dengan lingkungan kita, serta mendapatkan keanggotaan dan rasa memiliki dalam berbagai kelompok sosial yang mempengaruhi kita.

Komunikasi sebagai pembawa proses social karena ada alat yang manusia miliki untuk mengatur, menstabilkan, dan memodifikasi kehidupan sosialnya. Dalam proses sosial bergantung pada penghimpunan, pertukaran, dan penyampaian pengetahuan, pada gilirannya pengetahuan bergantung pada komunikasi. Dalam konteks yang luas ini, kita dapat merumuskan budaya sebagai panduan pola-pola yang merefleksikan respons-respons komunikatif terhadap rangsangan dari lingkungan. Pola-pola budaya ini dapat merefleksikan elemen-elemen yang sama dalam perilaku komunikasi individual yang dilakukan mereka yang lahir dan diasuh dalam budaya itu. Proses belajar yang terinternalisasikan ini memungkinkan kita untuk berinteraksi dengan anggotaanggota budaya lainnya yang juga memiliki pola-pola komunikasi serupa. Proses memperoleh pola-pola demikian oleh individu-individu itu disebut 
enkulturasi. Budaya mempengaruhi dan dipengaruhi oleh setiap fase aktivitas manusia, Dimana idividu-individu sangat cenderung menerima dan mempercayai apa yang dikatakan budaya mereka. Kita dipengaruhi oleh adat dan pengetahuan masyarakat di mana kita dibesarkan dan tinggal, terlepas dari bagaimana validitas objektif masukan dan penanaman budaya ini pada diri kita cenderung mengabaikan atau menolak apa yang bertentangan dengan kebenaran kultural atau bertentangan dengan kepercayaan-kepercayaan kita. Ini sering kali merupakan landasan bagi prasangka yang tumbuh di antara anggotaanggota kelompok-kelompok lain, bagi penolakan untuk berubah ketika gagasan-gagasan yang sudah mapan menghadapi tantangan. Masalah akan muncul bila suatu budaya dan cara berpikirnya tertinggal di belakang penemuan-penemuan dan realitas-realitas baru. Kemajuan-kemajuan ilmu dan teknologi, misalnya, telah jauh mendahului ajaran-ajaran kultural masyarakat. Ini merupakan salah satu efek sampingan akselerasi perubahan, yang menimbulkan jurang budaya (cultural gap). Budaya dan komunikasi tak dapat dipisahkan oleh karena budaya tidak hanya menentukan siapa bicara dengan siapa, tentang apa, dan bagaimana orang menyandi pesan, makna yang ia miliki untuk pesan, dan kondisi-kondisinya untuk mengirim, memperhatikan dan menafsirkan pesan. Sebenarnya seluruh perbendaharaan perilaku kita sangat bergantung pada budaya tempat kita dibesarkan. Konsekuensinya, budaya merupakan landasan komunikasi. Bila budaya beraneka ragam, maka beraneka ragam pula praktik-praktik komunikasi.
Internet dapat mengembangkan ruang gerak kehidupan baru bagi masyarakat. Tanpa disadari, masyarakat telah hidup dalam dua kehidupan, yakni kehidupan masyarakat nyata dan masyarakat maya. Sedikitnya waktu yang dimiliki individu untuk berinteraksi dengan individu lainnya menjadi permasalahan bagi masyarakat modern saat ini. Dunia maya menjadi alternatif bagi manusia modern untuk memenuhi kebutuhannya, yaitu kebutuhan untuk terikat pada lingkungannya, untuk bersatu dengan individu lainnya. Berbeda dengan dunia nyata, dunia maya tidak lagi mengenal batas jarak, ruang dan waktu. Individu dapat dengan mudah berinteraksi dengan individu di belahan dunia lain tanpa harus berada di tempat tersebut. Media sosial menjadi wadah bagi individu - individu maya untuk berkumpul, berbagi, atau berinteraksi satu sama lain. Hampir semua kegiatan interaksi sosial (tentunya bukan yang terkait dengan interaksi fisik) dilakukan melalui media sosial.

Kebebasan berekspresi seringkali menjadi semangat bagi individuindividu maya untuk terus bertahan di media sosial. Kondisi interaksi yang tidak menuntut tatap muka dengan lawan bicara memancing individu untuk lebih berani mengungkapkan ide. Kondisi interaksi yang diciptakan dunia maya berpeluang membuat manusia untuk memilih kebutuhan narsis, yaitu kebutuhan untuk mementingkan diri sendiri, mengacuhkan keberadaan orang lain. Kondisi ini tergambar dari bagaimana pengguna semakin impulsif mengungkapkan ide dan perasaannya tanpa memperhatikan etika-etika yang berlaku.Pada banyak kasus, media sosial sering dijadikan wadah untuk saling menjelekkan atau menyindir satu 
sama lain tanpa memikirkan situasi dan kondisi orang atau kelompok yang sedang diejek dan tanpa mengulas permasalahan yang sesuangguhnya. Situasi seperti ini dapat berlangsung secara intens, dimanapun dan kapanpun itu. Informasi-informasi yang disediakan menjadi sangat transparan, memancing reaksi individu lain sebagai bagian dari komunitas dunia maya. Situasi seperti ini kemudian melahirkan apa yang dinamakan cyberbullying atau cyberharrassment yang bisa dilakukan oleh siapapun yang bahkan tidak memiliki riwayat kekerasan sekalipun. Sehingga diperlukan literasi media atau melek media sebagai kegiatan pemberdayaan untuk meningkatkan sikap kritis masyarakat berdasarkan enkulturasi dan akulturasi budaya.

Berdasarkan uraian tersebut diatas, maka yang menjadi permasalahan dalam tulisan ini adalah bagaimana komunikasi media sosial dalam nilai nilai budaya pancasila?

\section{PEMBAHASAN}

Teknologi dapat mengubah cara manusia hidup misalnya, teknologi foto digital, smart phone, telah membuat perubahan gaya hidup secara fundamental dalam segala hal. Muncul media social yang bisa mengindoktrinasi pikiran setiap orang, setiap detik sepanjang hidup, adanya transportasi dan perdagangan online. Disamping itu mahasiswa mengunduh ilmu dari internet sehingga sumber ilmunya bukan hanya dari dosen saja. Ada situs Wikileaks yang tiba - tiba muncul dengan informasi yang mengagetkan, Hoax, ada gerakan melalui change.org, orang mudah menggunakan bahasa gaul yang hanya di mengerti oleh kalangannya sendiri.
Masalah bagi kita apakah Pancasila akan digerus oleh perubahan ini, atau justru semakin memantapkan pentingnya bagi Indonesia dan juga di perlukan bagi pergaulan antar bangsa, dan sikap kita terhadap alam. Pancasila bukan sekedar kontrak sosial yang di buat untuk hidup bersama dengan damai oleh masyarakat yang berbhineka, tapi ilmu dan keterampilan hidup yang akan menjadi jaring pengaman peradaban dunia, karena sifat lentur dan elastis seperti sutra sehingga tidak tercerai-berai lantaran sikap hidup yang independent, egosentriss, dan nasionalisme sempit.

Media sosial merupakan media bersifat online tools yang memfasilitasi interaksi antara penggunanya dengan cara pertukaran informasi, pendapat, dan peminatan. Media sosial terdiri dari beragam tools dan teknologi yang terdiri dari proyek gabungan (contoh: Wikipedia, Wikispaces), blogs (contoh: Wordpress), mikroblogs (contoh: Twitter), komunitas content (contoh: Youtube), situs jejaring sosial (contoh: Facebook, Instagram, Path), folksonomies atau tagging (contoh: delicious), virtual game worlds (contoh: World of Warcraft), virtual social worlds (contoh: Second Life), dan semua akses berbasis internet lainnya (Khan, 2013).

Komunikasi online berbeda dengan komunikasi satu arah (televisi, radio, maupun surat kabar), karena pengguna online tidak hanya membacanya, namun dapat merespon pesan saat itu juga. Untuk memahami bagaimana media sosial dapat mengakibatkan perubahan sosial, penting untuk memahami proses yang mendasarinya, diantaranya: 
a. Bergabung dengan suatu kelompok secara virtual.

b. Mendapat pesan dan updates mengenai kegiatan kelompok.

c. Membaca, memberi komentar atau posting mengenai suatu berita atau informasi.

d. Menerima atau mengirim pesan pribadi kepada ketua maupun anggota kelompok.

e. Membaca dan ikut serta pada pembicaraan transparan yang dapat diketahui semua anggota.

f. Mengintai di dalam grup yaitu membaca informasi didalam grup tanpa membuat anggota lain sadar bahwa ia adalah anggota dalam grup tersebut.

g. Berinteraksi dengan orang lain tanpa mempedulikan batasan sosial maupun lokasi.

Proses komunikasi dan interaksi untuk menyampaikan informasi dalam media social mengakibatkan terjadinya perubahan social budaya. Perubahan sosial budaya adalah suatu struktur sosial dan pola budaya dalam masyarakat yang mengalami perubahan akibat sifat dasar manusia yang selalu menginginkan perubahan. Perubahan sosial budaya yang disebabkan media sosial dapat bersifat positif maupun negatif. Perubahan yang bersifat positif dapat mempermudah komunikasi antar budaya, pertukaran pengetahuan, dan mempermudah transaksi bisnis. Perubahan yang bersifat negatif salah satunya adalah geger budaya (culture shock). Geger budaya terjadi akibat informasi yang diperoleh dari media sosial diterima begitu saja, diyakini kebenarannya dan diterapkan dalam kehidupan keseharian, walaupun sebenarnya tidak sesuai dengan budaya sekitar. Hal ini dapat menyebabkan perubahan nilai, norma, maupun aturan dalam berkomunikasi. Geger budaya ditimbulkan oleh kecemasan dan disebabkan karena kehilangan tanda-tanda, lambang-lambang dalam pergaulan sosial, di mana tandatanda tersebut meliputi seribu cara yang dilakukan untuk mengendalikan diri sendiri dalam situasi sehari-hari (Muliyana, 2000 ; 175). Komunikasi dalam media sosial dapat meng-akibatkan adanya perubahan-perubahan dalam unsur budaya. Samovar LA \& Porter RE (2009) mengatakan bahwa media sosial dapat mengakibatkan perubahan pada enam unsur budaya, yaitu:

\section{Media sosial membawa perubahan} pada kepercayaan (belief), nilai (values), dan sikap (attitudes).

Dengan media sosial, masalah hubungan seseorang dengan sang pencipta tidak lagi dianggap sebagai hubungan individual, tetapi kelompok. Seseorang dapat berbagi pengalaman rohaninya atau ucapan rasa syukur terhadap pecipta dengan orang lain maupun kelompok misalnya dengan menggunakan Facebook atau Twitter. Media sosial juga dapat mengubah nilai-nilai dalam masyarakat, misalnya budaya masyarakat Indonesia dikenal dengan budaya sopan santun. Dengan media sosial, terjadi pergeseran nilai karena seseorang dapat memberi kritik tajam, hujatan, bahkan makian secara langsung terhadap individu atau kelompok lain tanpa memikirkan konsekuensi pada sang terhujat. Media sosial juga menyebabkan perubahan sikap pada masyarakat. Salah satu contohnya adalah seseorang tak lagi menganggap pertemuan langsung atau silaturahmi sebagai sesuatu yang penting, karena dapat dilakukan hanya dengan chatting di media sosial. Sikap acuh tak acuh dan tidak 
peduli pada lingkungan sekitar juga merupakan dampak dari penggunaan media sosial yang banyak ditemukan.

\section{Pandangan dunia (worldview)}

Cara pandang sempit (tradisional) yang berubah menjadi cara pandang global (modern). Hal inilah yang sering mengakibatkan geger budaya. Sebagai contoh gaya berpacaran remaja di luar negeri yang cenderung bebas dan diupload pada Facebook atau media sosial lainnya, telah banyak diterapkan oleh remaja Indonesia, walaupun sebenarnya sangat bertentangan dengan budaya sekitar.

\section{Organisasi sosial}

Organisasi sosial yang dibentuk di media sosial seperti Facebook tidak lagi bersifat resmi dan terikat seperti di dunia nyata. Seorang anggota organisasi sosial di Facebook dapat sangat aktif maupun pasif, tidak ada keterikatan dan rasa tanggung jawab seperti pada dunia nyata. Tetapi justru hal inilah yang membuat sebagian besar masyarakat merasa tertarik untuk bergabung dengan organisasi pada media sosial.

\section{Tabiat manusia (human nature)}

Status pada Facebook maupun media sosial lain sering menunjukkan tabiat narsis, egosentris, ingin merasa lebih dari yang lain dan ingin menonjolkan kelebihan diri sendiri. Banyak juga yang terlihat berusaha membuka kekurangan dan memojokkan orang lain. Tabiat buruk yang dahulu ditutupi, sekarang jelas terpampang pada media sosial seseorang dengan atau tanpa disadari oleh pemilik akun tersebut.

\section{Orientasi kegiatan (activity orienta- tion)}

Orientasi kegiatan yang bersifat positif antara lain mengupload kegiatan untuk tujuan bisnis, perdagangan atau kegiatan sosial. Orientasi kegiatan yang bersifat negatif antara lain mengupload suatu kegiatan dengan tujuan pamer, atau membangun citra diri.

\section{Persepsi tentang diri sendiri dan orang lain (perseption on self and others)}

Perilaku pengguna Facebook yang berusaha membangun konsep diri mereka sendiri dengan menuliskan status pada laman Facebook mereka. Mengekspos diri sendiri untuk mendapat perhatian orang lain, misalnya dengan mengunduh (upload) foto untuk berlomba mendapatkan "like" dari orang lain.

Media sosial mempunyai manfaat baru yaitu memudahkan seseorang untuk memperoleh suatu hal yang diinginkannya, seperti: (a) arus informa-si yang dapat dengan mudah dan cepat diakses di mana saja dan kapan saja, (b) sebagai media transaksi jual beli, (c) sebagai media hiburan, contohnya game online, jejaring sosial, streaming video, dan lain-lain, (d) sebagai media komunikasi yang efisien, (e) sarana pendidikan dengan adanya buku digital. Menurut Frank Biocca dalam Littlejohn (1999:337) menyatakan bahwa karakteristik eksposur atau terpaan media dapat diukur melalui dimensi-diniensi berikut:

1. Selectivity (keniampuan memilih) yaitu kemampuan audience dalam menetapkan pilihan terhadap media dan isi yang akan dieksposenya. 
2. Intentionally (kesengajaan) yaitu tingkat kesengajaan audience dalam menggunakan media atau kemampuan dalam mengungkapkan tujuantujuan penggunaan media.

3. Utilitarianism (pemanfaatan) yaitu kemampuan audience untuk mendapatkan manfaat dari penggunaan media.

4. Involvement (keterlibatan) yaitu keikutsertaan pikiran dan perasaan audience dalam menggunakan media dan pesan media yang diukur dari frekuensi maupun intensitas.

5. Previous to influence, yaitu kemampuan untuk melawan arus pengaruh media.

Interaksi pada dasamya merupakan proses peyesuaian diri terhadap lingkungan sosial, bagaimana seharusnya seseorang hidup di dalam kelompoknya, baik di dalam kelompok kecil maupun kelompok masyarakat luas. Dengan demikian dapat dikatakan bahwa hubungan sosial (sosialisasi) merupakan hubungan antar manusia (interaksi sosial) yang saling membutuhkan mulai dari tingkat sederhana dan terbatas hingga yang amat kompleks. Interaksi sosial diartikan sebagai hubungan-hubungan sosial yang dinamis yang menyangkut hubungan antara orang-orang perorangan, antara kelompok-kelompok manusia, maupun antara orang perorangan dengan kelompok manusia. Faktor yang mendasari berlangsungnya interaksi sosial baik secara tunggal maupun secara bersamaan adalah imitasi, sugesti, identifikasi, dan simpati.

Interaksi sosial dikategorikan ke dalam dua bentuk, yaitu yang bersifat asosiatif dan disosiatif (Soekanto, 2003: 71). Interaksi sosial yang bersifat asosiatif, yakni hubungan antar individu yang mengarah kepada bentuk- bentuk asosiasi (hubungan atau gabungan) seperti (a) kerja sama, yaitu suatu usaha bersama antara orang perorangan atau kelompok untuk mencapai tujuan bersama, (b) akomodasi, yaitu suatu proses penyesuaian sosial dalam interaksi antara pribadi dan kelompok-kelompok manusia untuk meredakan pertentangan, (c) asimilasi, yaitu proses sosial yang timbul bila ada kelompok masyarakat dengan latar belakang kebudayaan yang berbeda, saling bergaul secara intensif dalam jangka waktu lama sehingga lambat laun kebudayaan asli mereka akan berubah sifat dan wujudnya membentuk kebudayaan baru sebagai kebudayaan campuran, dan (d) akulturasi, yaitu proses sosial yang timbul, apabila suatu kelompok masyarakat manusia dengan suatu kebudayaan tertentu dihadapkan dengan unsur-unsur dari suatu kebudayaan asing sedemikian rupa sehingga lambat laun unsur-unsur kebudayaan asing itu diterima dan diolah ke dalam kebudayaan sendiri, tanpa menyebabkan hilangnya kepribadian dari kebudayaan itu sendiri. Sedang interaksi sosial yang bersifat disosiatif meliputi (a) Persaingan, yaitu suatu perjuangan yang dilakukan perorangan atau kelompok sosial tertentu agar memperoleh kemenangan atau hasil secara kompetitif, tanpa menimbulkan ancaman atau benturan fisik di pihak lawannya, (b) Kontravensi adalah bentuk proses sosial yang berada di antara persaingan dan pertentangan atau konflik, dan (c) Konflik adalah proses sosial antar perorangan atau kelompok masyarakat tertentu, akibat adanya perbedaan paham dan kepentingan yang sangat mendasar.

Komunikasi dalam media sosial memberikan kemerdekaan seluas-luas- 
nya bagi para pengguna untuk mengekspresikan dirinya, sikapnya, pandangan hidupnya, pendapatnya, atau mungkin sekadar menumpahkan kekesalan. Termasuk memberikan kebebasan apakah media sosial akan digunakan secara positif atau negatif. Kita patut prihatin dengan kondisi saat ini, cukup banyak orang yang menggunakan media sosial untuk menyebarkan kebencian dan provokasi. Keadaan tersebut di satu sisi bisa menjadi potensi yang menguntungkan, namun di sisi lainnya bisa menjadi sebuah ancaman atau setidaknya akan memberikan dampak negatif yang mengarah pada perpecahan. Sebagaimana akhir - akhir ini penyebaran berita ujaran kebencian, bentuk-bentuk intoleransi dan informasi palsu (hoax) sedang marak menghiasi jagad media sosial Indonesia. Hal ini berlangsung khususnya pada situasi politik tertentu, misalnya pada saat Pemilu, Pilpres dan pada masa Pilkada serentak di beberapa wilayah di Indonesia, dimana terdapat indikasi adanya persaingan politik dan kampanye hitam yang juga dilakukan melalui media sosial. Karena melalui media sosial sangat mudah memprovokasi orang. Dimana masyarakat sebagai konsumen informasi bisa dilihat masih belum dapat membedakan mana informasi yang benar dan mana informasi yang palsu atau hoax belaka. Beberapa faktor mempengaruhi terjadinya hal ini diantaranya yaitu ketidaktahuan masyarakat dalam menggunakan media sosial secara bijaksana. Dengan mengatasnamakan kebebasan para pengguna internet dan media sosial khususnya banyak netizen yang merasa mempunyai hak penuh terhadap akun pribadi miliknya. Mereka merasa sahsah saja untuk menggunggah tulisan, gambar atau video apapun ke dalam akunnya. Meskipun terkadang mereka tidak sadar bahwa apa yang mereka unggah tersebu bisa saja melanggar etika berkomunikasi dalam media sosial.

Persoalan lainnya yang menyebabkan informasi palsu atau hoax menjadi semakin sulit dikendalikan adalah, adanya kebiasaan sebagian besar masyarakat yang ingin cepat berbagi informasi. Masyarakat Indonesia memang memiliki karakteristik 'suka bercerita' sehingga sifat ini juga terbawa dalam cara mereka berkomunikasi dengan menggunakan media sosial. Sering terjadi bahwa para pengguna media sosial ini membagikan sebuah informasi yang mereka dapatkan tanpa melakukan pengecekan terhadap kebenarannya. Mereka kadang bahkan tidak tau dari mana sumber berita atau siapa orang yang pertama-tama yang membuat berita tersebut. Banyak yang langsung percaya dan secara tergesagesa membagikan berita atau informasi tersebut kepada pengguna lainnya. Pengguna lain yang mendapat informasi ini juga acapkali juga memiliki kecenderungan yang sama dengan pengguna sebelumnya, tanpa menelisik lebih jauh tentang informasi dan berita yang ia terima, langsung membagikan kembali informasi yang didapatnya itu. Demikian terus berlanjut sehingga berita yang sebenarnya belum sempat divalidasi kebenarannya itu malah telah menjadi viral dan dipercaya oleh masyarakat.

Adapun Dampak baik yang didapat dari era digital adalah (a) Kemudahan dalam mendapatkan informasi dimanapun dan kapanpun; (b) Kemudahan berkomunikasi yang melebur batas jarak, ruang, dan waktu; (c) 
Mendukung untuk peningkatan bisnis kreatif. Sedangkan dampak negatif yang didapatkan dari internet antara lain:

a. Cyberbullying.

Kemampuan tata krama, etika berkomunikasi, rasa empati dan cara penyelesaian konflik yang dimiliki individu menjadi menurun. Karakteristik computer mediated communication yang anonim membuat netizen bisa bersikap dan berucap apa saja tanpa mendapatkan sanksi sosial langsung dari masyarakat. Orangorang yang melakukan cyberbullying biasanya berlindung dibalik pseudoidentity yang dibuatnya. Netizen yang kritis di dunia maya, belum tentu bisa bersikap kritis juga di dunia nyata.

\section{b. Unggahan kebencian.}

Penyebaran kebencian kepada sekelompok orang atau individu tertentu karena sentimen pribadi atau karena terpengaruh oleh isi media massa. Misalnya menjelekkan-jelekkan etnis dan agama tertentu.

c. Cyber crime.

Penipuan dan penyebaran ajaran radikalisme agama melalui media sosial.

Dengan pengetahuan masyarakat yang masih minim, maka penggiringan opini melalui berita bohong (hoax) sangat mudah sekali dilakukan. Faktor utama yang menyebabkan informasi palsu (hoax) mudah tersebar di Indonesia adalah karakter masyarakat Indonesia yang dinilai belum terbiasa berpendapat atau berdemokrasi secara sehat. Ancaman global yang dapat memecah belah persatuan dan kesatuan Indonesia, salah satunya dengan maraknya isu-isu berita hoax atau fake news, seringkali merupakan berita yang berisi fitnah dan berita bohong yang tersebar luas melalui perantaraan media sosial. Sulit untuk meredam penyebaran berita bohong atau hoax yang disebarkan oleh orang yang tidak bertanggungjawab tersebut. Setiap individu atau kelompok dapat dengan mudah menyebarkan berita yang tidak benar, dan penerima berita seringkali pula dinilai tidak kritis dalam mencerna pemberitaan apakah berita tersebut benar atau tidak.

Oleh karena itu, salah satu prinsip dalam pendidikan literasi media adalah memberdayakan khalayak. Disebut memberdayakan karena model literasi media menjadi kompas baru dalam mengarungi dunia media yang luas, sehingga orang tidak akan menjadi korban media (Brow, dalam Iriantara, 2009: 13). Tujuan literasi media adalah memberi kita kontrol yang lebih besar atas interpretasi terhadap muatan pesan media yang merupakan hasil dari suatu konstruksi kepentingan. Berkenaan dengan kepentingan untuk pemberdayaan khalayak diperlukan juga media untuk membangun khalayak yang berdaya tersebut. Hal ini berkenaan dengan tujuan untuk mencapai upaya melampaui melek- media. Dari sisi tujuan literasi media, ada dua pandangan utama yang berbeda dan memiliki pengaruh yang sama kuatnya di kalangan praktisi pendidikan media dan para penggiat literasi media (Aufderheide, 1992) yaitu

(1) Pandangan pertama yang disebut kelompok 'proteksionis' menyatakan, pendidikan media atau literasi media dimaksudkan untuk melindungi warga masyarakat sebagai konsumen media dari dampak negatif media massa.

(2) Pandangan kedua yang disebut 'preparasionis' yang menyatakan bahwa literasi media merupakan upaya mempersiapkan warga 
masyarakat untuk hidup di dunia yang sesak-media agar mampu menjadi konsumen media yang kritis. Artinya, dalam pandangan kelompok preparasionis, warga masyarakat secara umum perlu dibekali oleh kompetensi melek media untuk bisa mengambil manfaat dari kehadiran media massa.

Betapa manusia itu menggunakan pikiran dan berperilaku, untuk mewujudkan kebutuhan dan mengatasi kelemahannya, ia tidak terlepas dari pengaruh budaya dan alam lingkungannva. Manusia tidak terlepas dari apa yanq dilihat, didengar, dirasakan dan dijalaninya. la belajar dari sanak saudaranya, ia meniru teman sepergaulannya, ia memperhatikan alam sekitarnya. Untuk itu ia tidak akan mungkin bekerja sendiri tanpa bekerja sama dengan orang lain, digunakannya akal pikirannya dengan musyawarah dan mufakat dengan orang lain. Kemudian ia terbiasa dengan apa yang telah dianggapnya baik dan menjadikan kebiasaan itu sebagai jalan yang tetap yang harus ditempuhnya, ia tidak menghendaki terjadi pelanggaran terhadap kebiasaan itu, karena pelanggaran berarti gangguan keseimbangan.

Di samping itu kecenderungan manusia berperilaku tidak terlepas dari naluri dan perasaan yang ada pada dirinya. Menurut para ahli ilmu jiwa, naluri itu memang telah dibawa manusia sejak lahir, manusia dilahirkan mempunyai nafsu badaniah sebagaimana makhluk hewan. Keinginan yang timbul dari naluri itu merupakan "dorongan" (drive), doro- ngan nafsu itu jika tidak terkendali mendekati "nafsu binatang", seperti halnya dengan nafsu seks, nafsu bercampur dengan jenis lain, nafsu makan, nafsu mempertahankan nyawa, nafsu bergaul, nafsu untuk berhubungan dengan orang lain, dan sebagainya. Dorongan nafsu yang tidak terkendali dapat berakibat manusia berperilaku tindak pidana, dikarenakan terjadinya pertentangan dan perselisihan membawa akibat terjadinya penganiayaan. Begitu pula dikarenakan sifat egoisme, sifat mementingkan diri sendiri terlalu tinggi dan terlalu kecilnya sifat altruism atau sifat memperhatikan orang lainnya terlalu rendah, maka dapat berakibat terjadinya prilaku yang tidak berperikemanusiaan, atau yang disebut hukum rimba. Di samping adanya naluri manusia juga mempunyai perasaan yaitu kesadaran yang timbul dari dalam diri mannsia karena akal pikirannya sehat.

Perasaan yang dapat membedakan yang baik dan yang buruk, yang perlu dan tidak perlu, yang bermanfaat dan tidak bermanfaat, yang adil dan tidak adil, perasaanperasaan demikian itu menimbulkan keinginan orang seorang atau sekelompok masyarakat untuk mempertahankan prilaku yang baik sebagai kebiasaan dan kelaziman dalam kehidupan bermasyarakat. Kebiasaan dan kelaziman yang diterima dan dipakai masyarakat secara berulang, yang dijadikannya pedoman dan diterapkannya dalam pelaksanaan untuk mewujudkan kebahagiaan, kesejahteraan, keseimbangan, kerukunan, ketertiban, keadiian dan kedamaian dalam melangsung kan kehidupan masyarakat itu disebut adat. Jadi adat 
adalah suatu sistem kontrol-sosial. Adakalanya dikarenakan apersepsi manusia berubah karena melihat lingkungan alamnya berubah, maka timbul perasaan yang menginginkan adanya perubahan pula dalam menerapkan kaidah-kaidah adat itu. Dengan demikian manusia berusaha untuk mengubah sistem kontrol sosial yang lama dengan sistem kontrol sosialnya yang baru. Perubahan itu dapat terjadi dengan mengubah bagian-bagiannya atau mengubah keseluruhan dengan bentuk yang baru. Perubahan itu dapat berlaku dengan lambat atau dengan cepat, dengan cara membiarkan tidak berlaku atau menyatakannya tidak berlaku lagi, baik sistem kontrol sosial itu merupakan kebiasaan, atau adat atau pun hukum adat. Sebagaimana dikatakan Hoebel (Hadikusuma, 2006;8) hukum itu ada pada masyarakat yang sederhana dengan hukumnya yang sederhana yang dinamakan hukum masyarakat sederhana atau "primitive law", Hukum itu ada pada masyarakat purba dengan hukumnya yang purba atau "archaic law" dan Hukum itu ada pada masyarakat yang telah maju dengan hukumnya yang modern.

Jadi hukum itu ada jika ada masyarakat dan ada kekuasaan. Dengan demikian prilaku yang kemudian menjadi kebiasaan pribadi atau sekelompok manusia, yang selanjutnya menjadi adat masyarakat dan merupakan sistem kontrol sosial. Sehubungan dengan media sosial sudah di atur dalam UU No.11 Tahun 2008 tentang Informasi Transaksi Elektronik (ITE) sebagai kontrol sosial dalam menyampaikan informasi merupakan perwujudan dari UUDNRI 1945 pasal 28 yang berbunyi kemerdekaan ber-serikat dan berkumpul, mengeluarkan pikiran dengan lisan dan tertulis dan sebagainya di tetapkan dengan undang-undang. (Sekjen MPR, 2012 : 155).

Sejak disahkan secara konstitusional pada 18 Agustus 1945, Pancasila dapat dikatakan sebagai dasar (falsafah) negara, pandangan hidup, ideologi nasional, dan ligatur (pemersatu) dalam perikehidupan kebangsaan dan kenegaraan Indonesia. Singkat kata, pancasila adalah dasar statis yang mempersatukan sekaligus bintang penuntun (Leitstar) yang dinamis, yang mengarahkan bangsa dalam mencapai tujuannya. Dalam posisinya seperti itu, Pancasila merupakan sumber jati diri, kepribadian, moralitas, dan haluan keselamatan bangsa. Dengan demikian, Negara Indonesia memiliki landasan moralitas dan haluan kebangsaan yang jelas dan visioner. Suatu pangkal tolak dan tujuan pengharapan yang penting bagi keberlangsungan dan kejayaan bangsa.

Pokok-pokok moralitas dan haluan kebangsaan-kenegaraan menurut alam Pancasila dapat dilukiskan sebagai berikut: Pertama, menurut alam pemikiran Pancasila, nilai-nilai ketuhanan (religiositas) sebagai sumber etika dan spiritualitas (yang bersifat vertikaltransendental) dianggap penting sebagai fundamen etik kehidupan bernegara. Kedua, menurut alam pemikiran Pancasila, nilai-nilai kemanusiaan universal yang bersumber dari hukum Tuhan, hukum alam, dan bersifat sosial manusia (yang bersifat horizontal) dianggap penting sebagai fundamen etikapolitik kehidupan bernegara dalam pergaulan dunia. Prinsip kebangsaan yang 
luas yang mengarah pada persaudaraan dunia itu dikembangkan melalui jalan eksternalisasi dan internalisasi. Ketiga, menurut alam pemikiran Pancasila, akulturasi nilai-nilai etis kemanusiaan itu lebih dahulu harus mengakar kuat dalam lingkungan pergaulan kebangsaan yang lebih dekat sebelum menjangkau pergaulan dunia yang lebih jauh. Empat, menurut alam pemikiran Pancasila, nilai ketuhanan, nilai kemanusiaan dan nilai serta cita-cita kebangsaan itu dalam aktualisasinya harus menjunnjung tinggi kedaulatan rakyat dalam semangat permusyawaratan yang dipimpin oleh hikmat kebijaksanaan. Kelima, menurut alam pemikiran Pancasila, nilai ketuhanan, nilai kemanusiaan, nilai dan cita kebangsaan, serta demokrasi permusyawartan itu memperoleh kepenuhan arinya sejauh dapat mewujudkan keadilan sosial. (Latif Yudi, 2015 : 41).

Kini permasalahannya adalah bagaimana memperdalam pemahaman, penghayatan, dan kepercayaan akan keutamaan nilai-nilai yang terkandung pada setiap sila Pancasila dan kesalingterkaitannya satu sama lain, untuk kemudian diamalkan secara konsisten di segala lapis dan bidang kehidupan berbangsa dan bernegara. Dalam konteks ini, yang diperlukan adalah apa yang disebut Kuntowijoyo dengan proses "radikalisasi Pancasila".( Latif Yudi, 2015 : 47).

Radikalisasi dalam arti ini adalah revolusi gagasan, demi membuat Pancasila tegar,efektif, dan menjadi petunjuk bagaimana negara ini ditatakelola dengan benar. Radikalisasi Pancasila yang dimaksudkannya ialah (1) mengembalikan Pancasila sebagai ideologi negara, (2) mengembangkan
Pancasila sebagai ideologi menjadi Pancasila sebagai ilmu, (3) mengusahakan Pancasila mempunyai konsistensi dengan produk-produk perundangan, koherensi antarsila, dan korespondensi dengan realitas sosial, (4) Pancasila yang semula hanya melayani kepentingan vertikal (negara) menjadi Pancasila yang melayani kepentingan horizontal, dan (5) menjadikan Pancasila sebagai kritik kebijakan negara.

Proses radikalisasi itu dimaksudkan untuk membuat Pancasila menjadi lebih operasional dalam kehidupan dan ketatanegaraan dan sanggup memenuhi kebutuhan praktis atau pragmatis dan bersifat fungsional. Pemikiran-pemikiran lain yang bersifat abstraksi-filosofis juga bukan tanpa makna. Justru, pemikiran yang bersifat abstraksi-filosofis menjadi lebih bermakna sejauh diberi kaki operasionalisasinya agar bisa menyejarah dan memiliki makna bagi kehidupan kebangsaan dan kenegaraan.

Tidak dapat di pungkiri manusia adalah aktor yang berusaha untuk menggabungkan karakteristik personal dan tujuan kepada orang lain melalui "pertunjukan dramanya sendiri". Dalam mencapai tujuannya tersebut, para pengguna media sosial instagram dalam hal ini akan mengembangkan perilakuperilaku yang mendukung perannya tersebut. Selayaknya pertunjukan drama, seorang aktor drama kehidupan juga harus mempersiapkan kelengkapan pertunjukan. Kelengkapan ini antara lain memperhitungkan setting seperti lokasi foto yang ia posting, kostum atau pakaian yang digunakan para pengguna akun instagram saat memposting fotonya dengan framing "Saya Indonesia Saya Pancasila", penggunaan kata 
dalam status instagramnya ataupun dialog yang terjadi pada kolom komentar, serta tindakan non verbal lainnya seperti pemilihan icon emotion. Hal ini tentunya bertujuan untuk meninggalkan kesan yang baik pada lawan interaksi dan memuluskan jalan agar mencapai tujuan. Goffman mengungkapkan bahwa tindakan di atas disebut sengaja menampilkan diri atau (self-presentation) seperti yang ia hendaki dengan istilah "impression management". Menurut Goffman (1966:229) pengelolaan kesan atau impression management dibutuhkan ketika kesulitan persepsi timbul karena persona stimuli berusaha menampilkan petunjuk-petunjuk tertentu untuk menimbulkan kesan tertentu pada diri penanggap. Orang lain menilai berdasarkan petunjuk-petunjuk yang pribadi berikan, dan dari penilaian itu mereka memperlakukan pribadi itu sendiri. Bila mereka menilai pribadi status rendah, pribadi tidak mendapatkan pelayanan istimewa. Bila pribadi dianggap bodoh, mereka akan mengatur pribadi. (Jalaludin 2007:96).

Hal tersebut dipertegas lagi dalam teori dramaturgi Erving Goffman. Teori Dramaturgi merupakan sebuah teori yang menjelaskan bahwa di dalam kegiatan interaksi satu sama lain sama halnya dengan pertunjukkan sebuah drama. Dalam hal ini, manusia merupakan aktor yang menampilkan segala sesuatu untuk mencapai tujuan tertentu melalui drama yang dilakukannya. Identitas seorang aktor dalam berinteraksi dapat berubah, tergantung dengan siapa sang aktor berinteraksi (Widodo, 2010:167). Menurut Goffman orang berinteraksi adalah ingin menyajikan suatu gambaran diri yang akan diterima orang lain, yang disebut sebagai pengeloalan pesan. Asumsi dari teori dramaturgi adalah bahwa Goffman tidak berupaya menitik beratkan pada struktur sosial, melainkan pada interaksi tatap muka atau kehadiran bersama (co-presence). Menurutnya interaksi tatap muka itu dibatasinya sebagai individu yang saling memperngaruhi tindakan-tindakan mereka satu sama lain ketika masingmasing berhadapan secara fisik (Supardan,2011:158). Begitu pula dengan interaksi yang dilakukan oleh satu pengguna dengan pengguna lain di media sosial instagram. Instagram merupakan panggung sandiwara (front stage) yang dijadikan individu sebagai media untuk menampilkan dirinya karena ada pengguna instagram lain yang melihat atau menonton. Karena ada yang melihat atau menonton maka individu berusaha memperlihatkan kebaikan dari dirinya. Sedangkan ketika seorang individu sedang ada di dunia nyata (back stage) maka yang terlihat adalah bisa sebaliknya. Kaum dramaturgis memandang manusia sebagai aktor-aktor di atas panggung metaforis yang sedang memainkan peran-peran mereka.

Dalam perspektif dramaturgi, kehidupan ini ibarat teater, interaksi sosial yang mirip dengan pertunjukan di atas panggung, yang menampilkan peran-peran yang dimainkan para aktor. Untuk memainkan peran tersebut, biasanya sang aktor menggunakan bahasa verbal dan menampilkan perilaku nonverbal tertentu serta mengenakan atribut-atribut tertentu, misalnya kendaraan, pakaian, dan asesoris lainnya yang sesuai dengan perannya dalam situasi tertentu. Aktor harus memusatkan pikiran agar dia tidak keseleo-lidah, menjaga kendali diri melakukan gerak- 
gerik, menjaga nada suara dan mengekspresikan wajah yang sesuai dengan situasi.

Menurut Goffman kehidupan sosial itu dapat dibagi menjadi "panggung depan" (front stage) dan "panggung belakang" (back stage). Panggung depan merujuk kepada peristiwa social yang menunjukkan bahwa individu bergaya atau menampilkan peran formalnya. Mereka sedang memainkan perannya di atas panggung sandiwara di hadapan khalayak penonton. Sebaliknya panggung belakang ibarat atau kamar rias tempat pemain sandiwara bersantai, mempersiapkan diri, atau berlatih untuk memainkan perannya di panggung depan.

Untuk menetralisir keadaan atau situasi terebut setiap individu harus belajar dengan memperbaiki kesalahan, kalau sadar telah membuat kesalahan, dan langsung diperbaiki, itulah hakikat belajar sepanjang hidup. Kalau kesalahan tidak diperbaiki dan bahkan dipertahankan karena harga diri, maka itu adalah benar-benar kesalahan. Seperti cara keija fisikawan kuantum yang dimulai dengan mengembangkan suatu model untuk memahami phenolmena alam bahkan sampai mendapat hadiah Nobel, namun bila temyata tidak bisa menyelesaikan masalah, tanpa keraguan langsung diperbaiki. Alvin Toffler menyebutkan proses belajar seperti ini sebagai "learn-unlearnrelearn". Kendatipun demikian, betapapun manusia sudah belajar, tetap harus rendah hati karena akhimya harus pasrah kepada Tuhari/Langit/Tian. (Sutanto, 2017 ; 23).

Aktualisasi sikap dasar budaya bangsa Indonesia itu dalam kehidupan sehari-hari pada hakikatnya adalah sikap yang menjunjung tinggi persatuan, keterpaduan, keseimbangan dan keserasian dalam kehidupan insani, masyarakat, bangsa dan negara, serta dalam hubungannya dengan Sang Pencipta dan alam lingkungannya. Dalam hubungannya dengan nilai-nilai vang terkandung di dalam Paneasila, pembukaan UUD NRI 1945 dan daiam pribadi bangsa Indonesia, yangperlu diperhatikan ialah nilai-nilai yang telah disepakati oleh bangsa Indonesia sehingga mempunyai kekuatan yang mengikat, lebih tinggi dan nilai-nilai yang sedang hidup berkembang dalam masyarakat yang masih memerlukan kristalisasi. Meskipun di lihat dari segi hukum norma-norma hukum mempunyai kekuatan mengikat yang lebih tinggi dan sanksi yang lebih kuat (dapat memaksakan pelaksanaannya), di lihat dari segi kemanfaatan, norma hukum dan bukan norma hukum mempunyai pengaruh timbal-balik. saling mengisi.

Oleh sebab itu pengamalan Pancasila sebagai pandangan hidup bangsa berarti melaksanakan Pancasila dalam hidup sehari-hari. Pengamalan Pancasila sebagai dasar negara disebut pengamalan Pancasila secara obyektif, sedangkan pengamalan Pancasila sebagai pandangan hidup bangsa disebut pengamalan secara subyektif. Pengamalan Pancasila secara subyektif meliputi bidang yang luas antara lain ekonomi, politik, sosial budaya, hankam, agama dan kepercayaan terhadap Tuhan Yang Maha Esa. Meliputi juga lingkungan hidup pribadi, hidup keluarga, hidup kemasyarakatan. Kesemuanya harus di pertanggung jawabkan secara obyektif, secara filosofis, secara sosiologis dan secara moral dan etis sesuai dengan keadaan dan kapan 
dilaksanakan, ditentukan waktu dan tempat, baik sendiri maupun bersamasama. Pengamalan secara subyektif inilah yang pertama (primer). Bahkan yang menentukan: artinya pengamalan obyektif hanya dapat berlangsung dengan baik apabila terlebih dahulu pengamalan subyektif pancasilah sudah dapat terlaksanakan dengan baik. Untuk menuju terwujudnya pengamalan subyektif yang baik, maka secara bertahap sebaiknya di tempuh melalui pendidikan. Sebab melalui pendidikan inilah, kepada para subyek (manusiamanusianya) akan dapat diberikan pengertian dan pengetahuan yang tepat mengenal arti dan makna dari pada nilai-nilai Pancasila. Sehingga dengan pengetahuannya yang tepat atau yang baik, barulah dapat diharapkan tumbuhnya kesadaran, dan kemudian dari rasa kesadaran diharapkan adanya rasa ketaatan dan kemampuan untuk mengamalkan nilai-nilai Pancasila dalam kenyataan hidup sehari-hari, tanpa menghilangkan jati diri sebagai bangsa yang memiliki karakter yang berbeda dengan bangsa - bangsa lain di dunia yakni ramah, santun, dan menghargai kelebihan orang lain serta mengakui kekurangan diri sendiri dengan penuh tanggung jawab sebagai bangsa yang beradab, berdasarkan nilai - nilai budaya Pancasila seperti makna dari judul lagu Pancasila Rumah Kita.

\section{PENUTUP}

Komunikasi dalam media sosial memberikan kemerdekaan seluas-luasnya bagi para pengguna untuk mengekspresikan dirinya, sikapnya, pandangan hidupnya, pendapatnya, atau mungkin sekadar menumpahkan kekesalan. Termasuk memberikan kebebasan apakah media sosial akan digunakan secara positif atau negatif. Kita patut prihatin dengan kondisi saat ini, cukup banyak orang yang menggunakan media sosial untuk menyebarkan kebencian dan provokasi.

Dengan pengetahuan masyarakat yang masih minim, maka penggiringan opini melalui berita bohong (hoax) sangat mudah sekali dilakukan. Faktor utama yang menyebabkan informasi palsu (hoax) mudah tersebar di Indonesia adalah karakter masyarakat Indonesia yang dinilai belum terbiasa berpendapat atau berdemokrasi secara sehat. Ancaman global yang dapat memecah belah persatuan dan kesatuan Indonesia, salah satunga dengan maraknya isu-isu berita hoax atau fake news, seringkali merupakan berita yang berisi fitnah dan berita bohong yang tersebar luas melalui perantaraan media sosial. Sulit untuk meredam penyebaran berita bohong atau hoax yang disebarkan oleh orang yang tidak bertanggungjawab tersebut. Setiap individu atau kelompok dapat dengan mudah menyebarkan berita yang tidak benar, dan penerima berita seringkali pula dinilai tidak kritis dalam mencerna pemberitaan apakah berita tersebut benar atau tidak.

Oleh karena itu, salah satu prinsip dalam pendidikan literasi media adalah memberdayakan khalayak. Disebut memberdayakan karena model literasi media menjadi kompas baru dalam mengarungi dunia media yang luas, sehingga orang tidak akan menjadi korban media. Sehubungan dengan media sosial sudah di atur dalam UU No.11 Tahun 2008 tentang Informasi Transaksi Elektronik (ITE) sebagai kontrol sosial dalam menyampaikan informasi merupakan perwujudan dari UUDNRI 1945 pasal 28. Pancasila merupakan sumber jati diri, kepribadian, moralitas, 
dan haluan keselamatan bangsa. Dengan demikian, Negara Indonesia memiliki landasan moralitas dan haluan kebangsaan yang jelas dan visioner. Suatu pangkal tolak dan tujuan pengharapan yang penting bagi keberlangsungan dan kejayaan bangsa.

\section{DAFTAR PUSTAKA}

BUKU :

Aufderheide, Patricia. 1992. Media Literacy. A Report of the National Leadership Conference on Media Literacy. Queenstown Maryland: The Aspen Institute Wye Center.

Goffman, Erving. 1966. Behavior in Public Places: Notes on the Social Organization of Gatherings.New York: The Free Press.

Hadikusuma Hilman. 2006. Antropologi Hukum Indonesia. Alumni Bandung

Iriantara, Yosal. 2009. Literasi Media: Apa, Mengapa, Bagaimana. Bandung: Simbiosa Rekatama Media

Khan GF, Swar B, Lee KS. (2013). Social Media Risks and Benefits: A Public Sector Perspective. KoreaTECH, Korea.

Littlejhon Stephen W. 1999. Theories of Human Communication. $6^{\text {th }}$ Edition. Belmont CA: Wadsworth Publishing Company.

Latif Yudi.2015. Negara Paripurna Historisitas, Rasionalitas, dan Aktualisasi Pancasila. Jakarta : Gramedia Pusat Utama.

Muliyana Deddy, Jalaluddin Rachmat.2008. Komunikasi Antar Budaya. Remaja Rosda Karya.
Rakhmat, Jalaluddin. 2007.Psikologi

Komunikasi. Bandung: Remaja

Rosdakarya.

Samovar LA, Porter RE, McDaniel ER. (2010). Communication Between Cultures. Cengage Learning, America.

Supardan, Dadang. 2011.Pengantar Ilmu Sosial: Sebuah Kajian Pendekatan Struktural. Jakarta: PT. Bumi Aksara.

Sutanto Yusuf. 2017. Pancasila Taksit, Jakarta : Peneliti Pusat Studi Pancasila Univ. Pancasila

Soekamto Soerjono. 2003. Sosiologi Suatu Pengantar. Jakarta : Grafindo Persada

Widodo, Suko. 2010. Anatomi danPerkembangan Teori Sosial. Malang: Aditya Media Publishing.

\section{PERUNDANG - UNDANGAN : UUD NRI 1945}

UU ITE No. 11 Tahun 2008

JURNAL :

Agus Efendi, Puwani Indri Astuti, dan Nuryani Tri Rahayu. Analisis Pengaruh Penggunaan Media Baru Terhadap Pola Interaksi Sosial Anak di Kabupaten Sukoharjo : Jurnal Penelitian Humaniora, Vol. 18, No. 2, Agustus 2017. 12-24.

Anisa Setya Arifina. Literasi Media Sebagai Manajemen Konflik Keagamaan di Indonesia: Jurnal Komunikasi dan Kajian Media, Vol. 1, No.1, Oktober $2017.43-56$.

Dio Herman Saputro dan Anisa Diniati. Manajemen Kesan Pengguna Media Sosial Intagram dalam Megeksistensikan Pancasila : 
Wacana, Vo. 16, No. 1, Juni 2017. 57 - 83.

Fahmi Anwar. Perubahan dan Permasalahan Media Sosial: Jurnal Muara Ilmu Sosial, Humaniora, dan Seni, Vol. 1, No. 1, April 2017. 137 - 144. Sulis Winurini. Media Sosial dan

Tantangan Mewujudkan Masyarakat yang Sehat : Info Singkat Kesejahteraan Sosial, Vol. 6, No.

21/I/P3DI/November 2014. 9 12.

Yoga Maulana Putra. Pengaruh Penggunaan Media Sosial Twitter Terhadap Pemenuhan
Kebutuhan Informasi Tugas Akhir (Survei Terhadap Followers@TA_FEB): eProceeding of Management, Vo. 2, No. 1, April 2015. 150. Vibriza Juliswara. Menggembangkan Model Literasi Media yang Berkebhinekaan dalam Menganalisis Informasi Berita Palsu (Hoax) di Media Sosial : Jurnal Pemikiran Sosiologi, Vol. 4, No. 2, Agustus 2017. $142-164$. 